\title{
Functions and Requirements for Russian Pulsating Monitor Deployment in the Gunite and Associated Tanks at Oak Ridge National Laboratory
}

January 1999

Prepared for the U.S. Department of Energy under Contract DE-QC06-76RLO 1830

Pacific Northwest National Laboratory

Richland, Washington 99352 


\title{
Functions and Requirements Document
}

\author{
for \\ Russian Pulsating Monitor Deployment in the \\ Gunite and Associated Tanks \\ at
}

Oak Ridge National Laboratory

January, 1999

Approved by:

Date:

S. D. Van Hoesen

Concurred by:

Date:

D. H. Bolling 


\section{Summary}

This document provides functions and requirements to support deployment of pulsating mixer pump technology in the Oak Ridge National Laboratory (ORNL) Gunite and Associated Tanks to mobilize and mix the settled sludge and solids in these tanks.

In FY 1998 pulsating mixer pump technology, a jet mixer powered by a reciprocating air supply, was selected for FY 1999 deployment in one of the GAAT tanks to mobilize settled solids. Pulsating mixer pump technology was identified in FY 1996 during technical exchanges between the US Department of Energy (DOE) Tanks Focus Area Retrieval and Closure program, the DOE Environmental Management International Programs, and delegates from Russia as a promising technology that could be implemented in the United States. The pulsating mixer pump technology, provided by the Russian Integrated Mining Chemical Company, was tested at Pacific Northwest National Laboratory (PNNL) to observe its ability to mobilize settled solids. Based on the results of this demonstration, ORNL and DOE staff determined that a modified pulsating mixer pump would meet project needs for bulk mobilization of Gunite tank sludge prior to deployment of other retrieval systems. The deployment of this device is expected to significantly reduce the costs of operation and maintenance of more expensive retrieval systems.

The functions and requirements presented here were developed by evaluating the results and recommendations that resulted from the pulsating mixer pump demonstration at PNNL, and by coupling this with the remediation needs identified by staff at ORNL involved with the remediation of the Gunite and Associated Tanks. 


\section{Acronyms}

ANSI American National Standards Institute

ASME American Society of Mechanical Engineers

CERCLA Comprehensive Environmental Response, Compensation, and Liability Act of 1980

DOE U.S. Department of Energy

FY Fiscal year begins October 1 and ends September 30.

GAAT Gunite and Associated Tanks. Refers to the underground waste storage tanks in the North and South tank farms at ORNL.

GAAT TS Gunite and Associated Tanks Treatability Study. A project started in FY 1994 to support a record of decision on remediation of waste at ORNL.

ORNL Oak Ridge National Laboratory. The Federal Government facility at Oak Ridge, Tennessee, where the pulsating monitor system will be employed.

PNNL Pacific Northwest National Laboratory. The Federal Government facility in Richland, Washington, where the pulsating monitor system was demonstrated in FY 1997.

RI/FS Remedial Investigation and Feasibility Study

STF South Tank Farm - Tanks W -5 through W -10 of the GAAT

TOC Total organic carbon. 


\section{Contents}

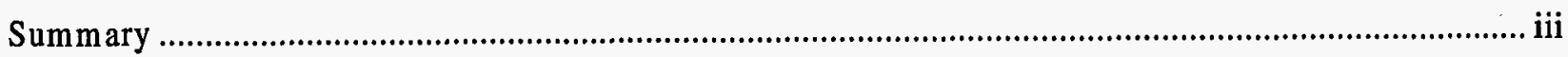

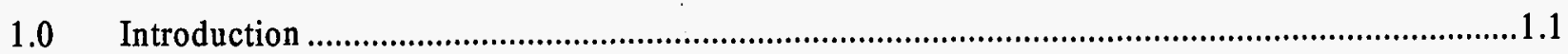

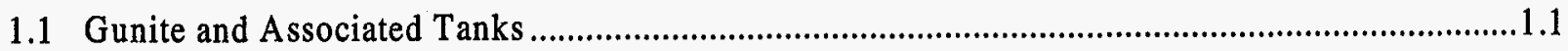

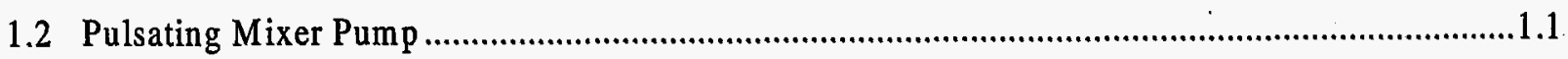

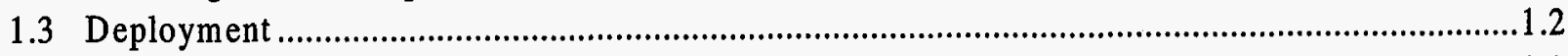

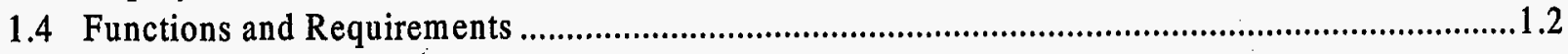

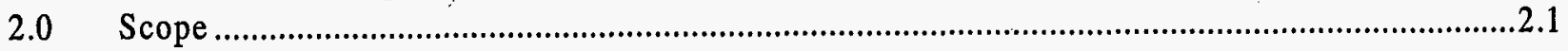

3.0 Pulsating Monitor Description and Performance .....................................................................

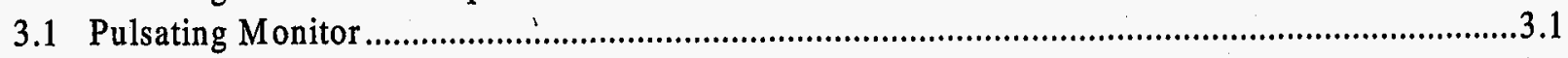

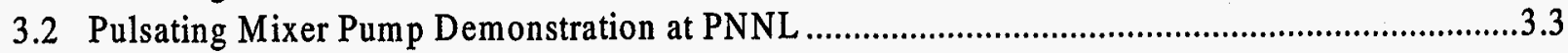

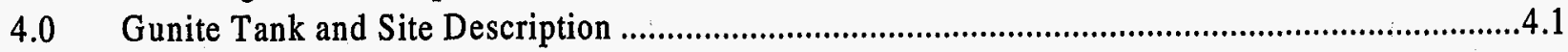

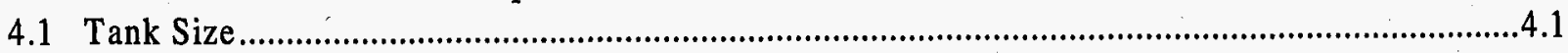

4.2 Tank Construction ................................................................ Error! Bookmark not defined. 4.1

4.3 Tank Position........................................................................ Error! Bookmark not defined.4.2

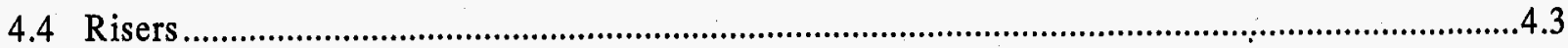

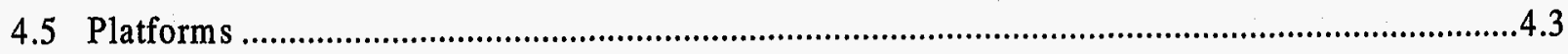

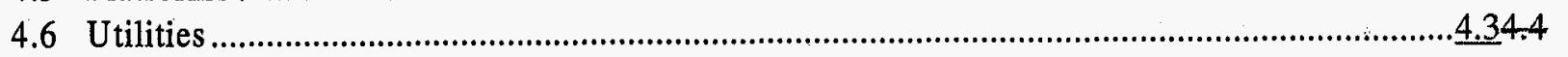

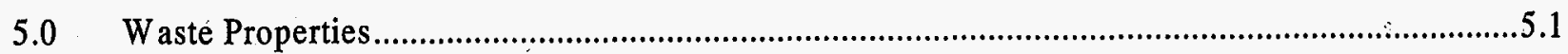

6.0 Pulsating Monitor Components, Functions, and Requirements ..............................................6.1

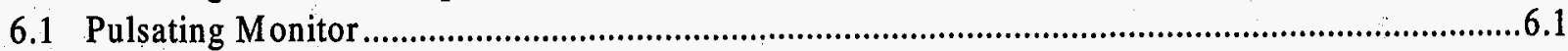

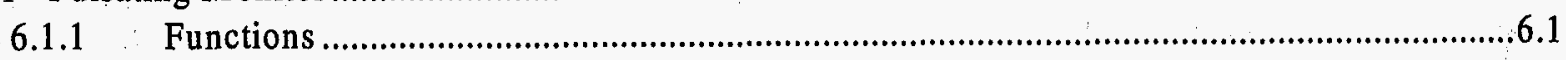

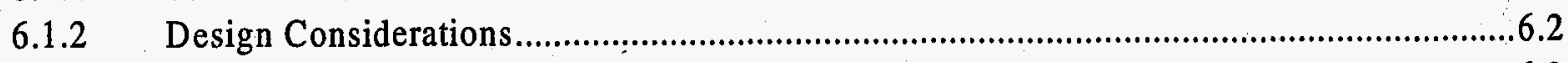

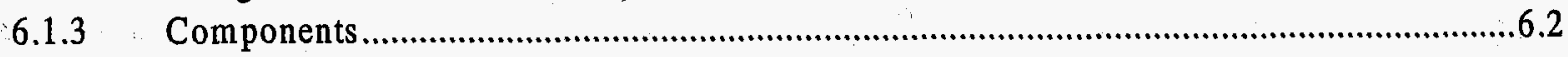

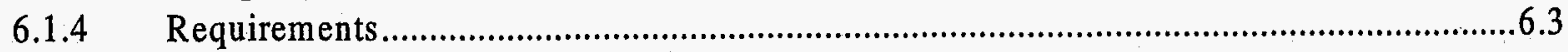

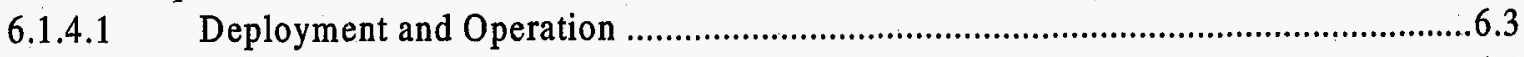

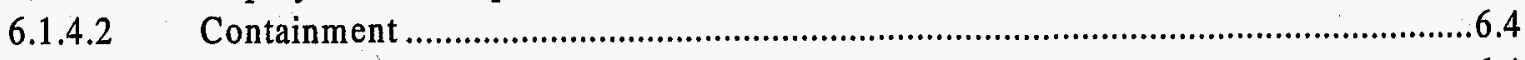

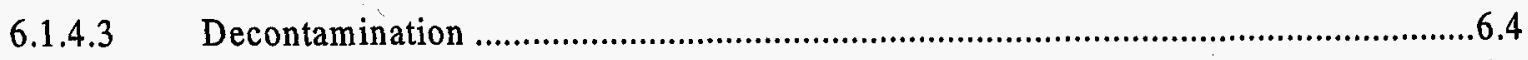

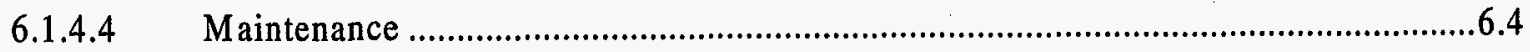

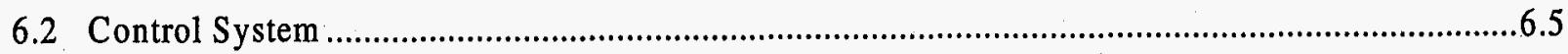

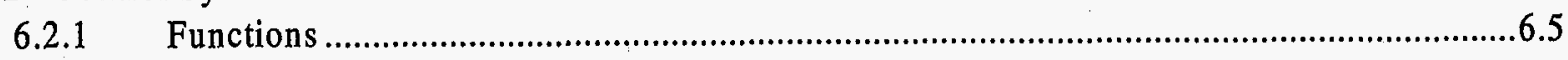

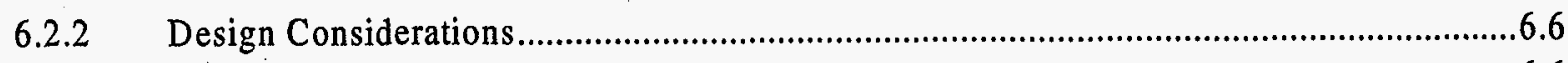

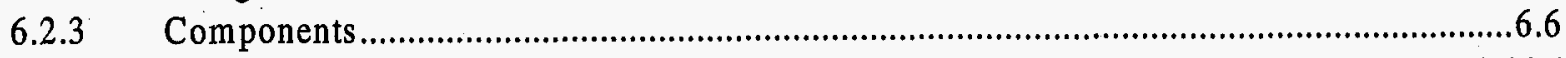

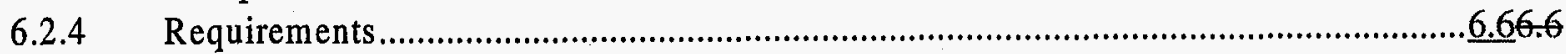

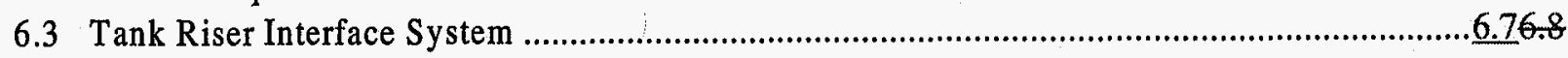

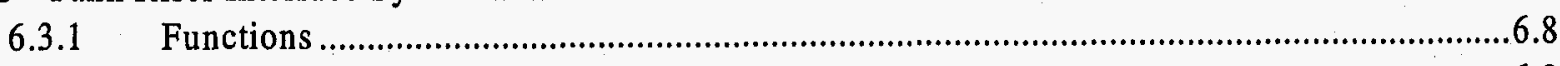

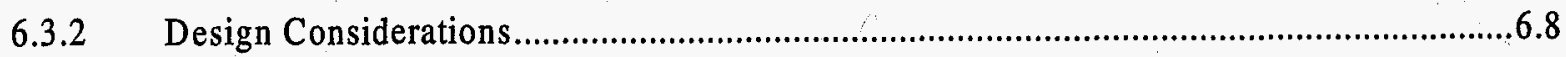

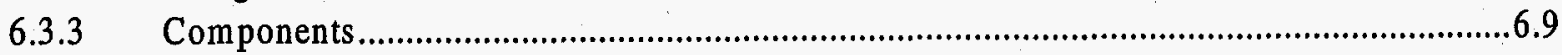

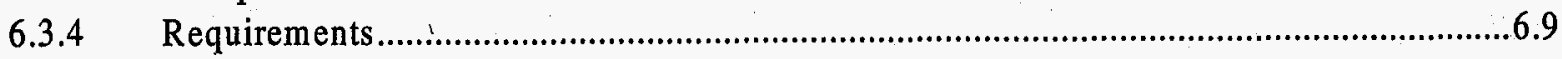

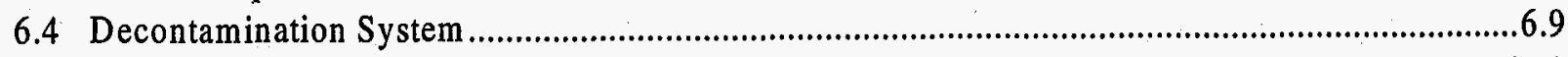

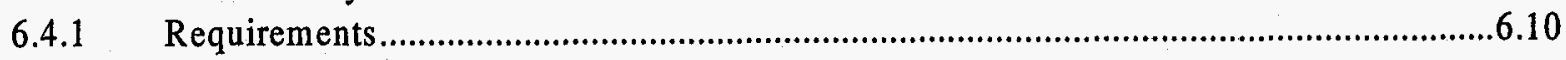

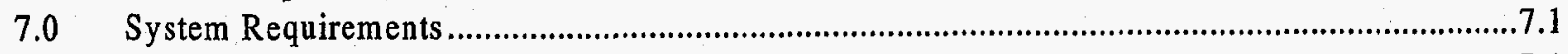

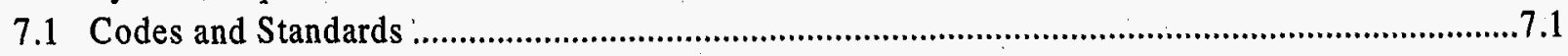

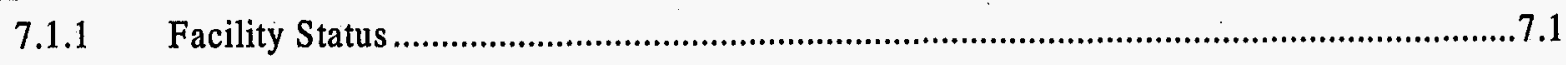




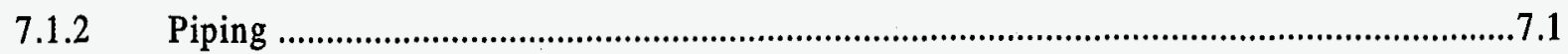

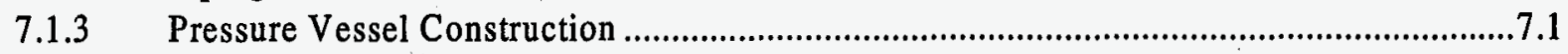

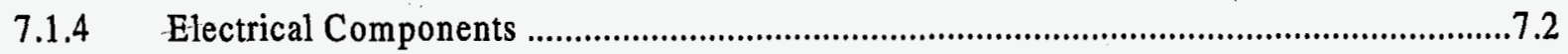

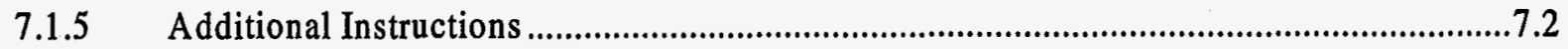

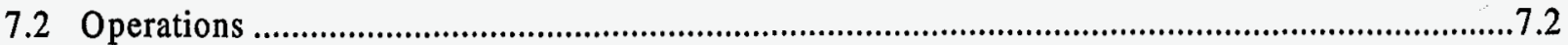

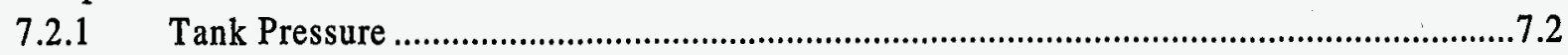

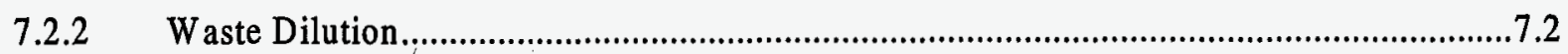

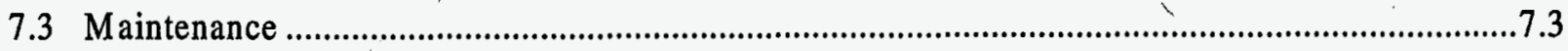

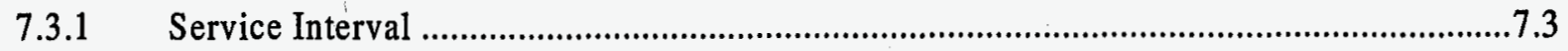

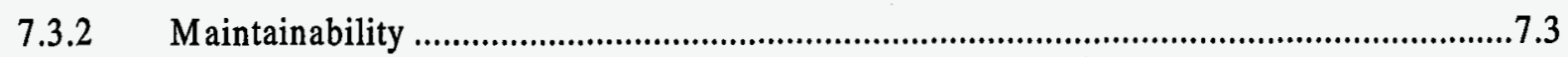

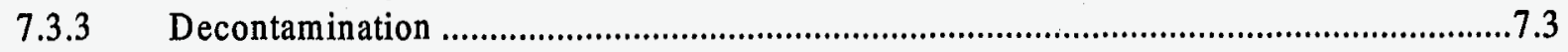

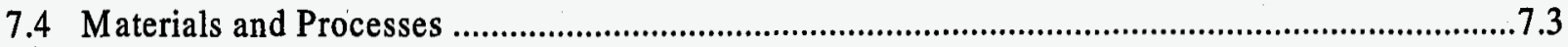

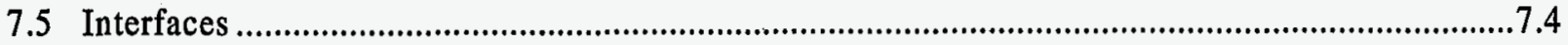

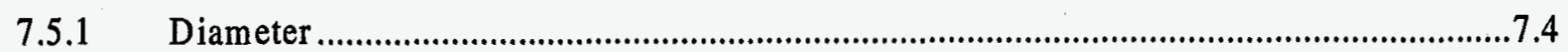

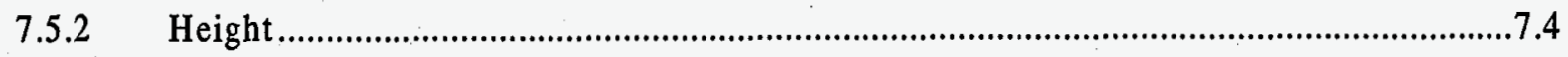

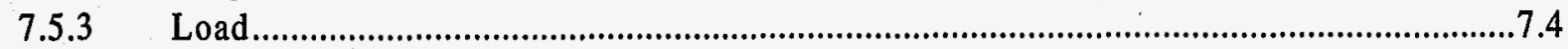

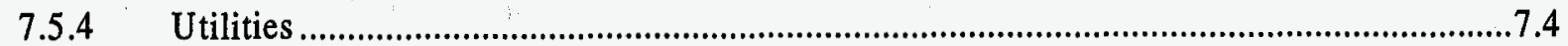

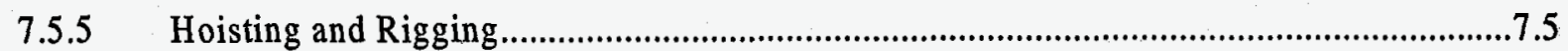

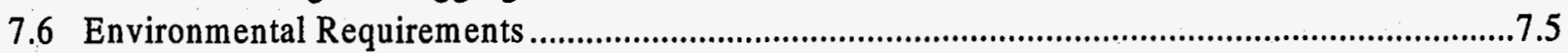

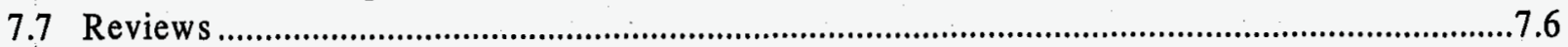

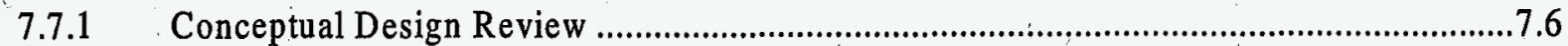

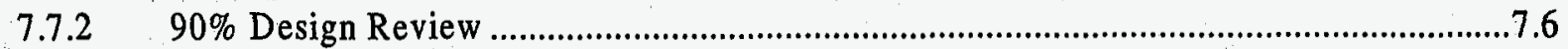

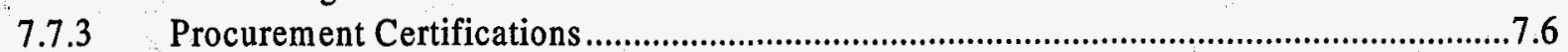

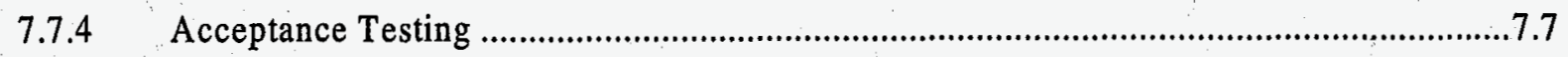

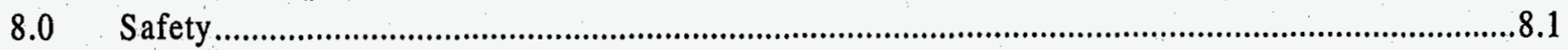

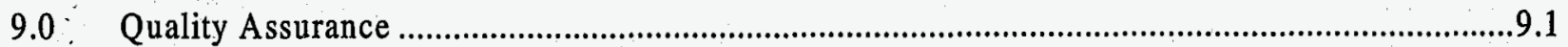

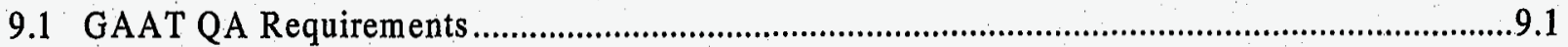

9.2 ORNL QA Requirements ...................................................... Error! Bookmark not defined 9.4

9.3 DOE QA Requirements.......................................................... Error! Bookmark not defined.9.1

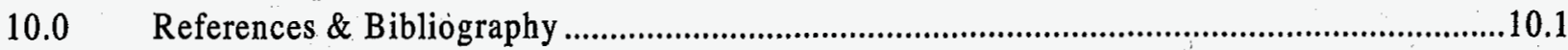




\subsection{Introduction}

Since the mid 1940's, the U.S. Department of Defense and the U.S. Department of Energy (DOE) have conducted research and development activities at the Oak Ridge National Laboratory (ORNL) in support of urgent national interests in the fields of nuclear weaponry and nuclear energy. Some of these activities resulted in hazardous radiological waste being temporarily deposited at ORNL, Waste Area Grouping 1 . At this location, waste is stored in several underground storage tanks, awaiting ultimate final disposal. There are tanks of two basic categories; one category is referred to as the "Gunite" tanks and the other category is "associated" tanks.

\subsection{Gunite and Associated Tanks}

The ORNL Gunite and Associated Tanks Treatability Study (GAAT TS) project was initiated in fiscal year (FY) 1994 to support a record of decision in selecting from seven different options of technologies for retrieval and remediation of these tanks. This decision process is part of a Comprehensive Environmental Response, Compensation, and Liability Act of 1980 (CERCLA) Remedial Investigation and Feasibility Study (RI/FS) presented to DOE and the Tennessee Department of Environment and Conservation. As part of this decision process, new waste retrieval technologies were evaluated at the $7.6 \mathrm{~m}$ (25-ft) diameter Gunite tanks in the North tank farm.

\subsection{Pulsating Mixer Pump}

During technical exchanges in FY 1996 between the US Department of Energy Tanks Focus Area Retrieval and Closure program, the DOE Environmental Management International Programs, and delegates from Russia, pulsating mixer pump (PMP) technology was identified as a promising technology that could be implemented in the United States. The PMP is a jet mixer powered by a reciprocating air supply. The PMP technology, provided by the Russian Integrated Mining Chemical Company, was evaluated as a potential retrieval tool in FY 1997 at Pacific Northwest National Laboratory (PNNL). Based on the evaluation, ORNL and DOE staff determined that a modified PMP would meet project needs for bulk mobilization of Gunite tank sludge prior to deployment or in conjunction with other retrieval systems. In FY 1998, PMP technology was selected for FY 1999 deployment in one of the GAAT tanks to mobilize settled solids. Deployment of the PMP is expected to reduce operation and maintenance costs required to utilize more expensive retrieval systems. 


\subsection{Deployment}

The PMP is scheduled for deployment in one of six Gunite tanks located in the South Tank Farm or tank TH-4 at ORNL. The tank selected will be identified based on the availability of the PMP. The anticipated South Tank Farm retrieval schedule is for remote systems to be deployed to tank W-8 following completion of tank W-10, approximately September 1999. Tank W-9, which is used as a receiver tank for waste retrieved from other tanks, may also be considered as a deployment site for the PMP. Waste removal will follow the completion of tank W-8, with equipment selection depending on the tank condition after MVST transfers.

\subsection{Functions and Requirements}

The functions and requirements for the design and construction of the PMP system to be deployed at ORNL are addressed in this document. 


\subsection{Scope}

This document describes the functions and requirements for design and construction of a pulsating mixer pump (PMP) system that can serve many sludge mobilization applications. The particular application addressed by this document is the hot deployment of the PMP system to reduce retrieval costs and enhance current mobilization and mixing in the ORNL Gunite tanks. These functions and requirements include: 1) high-level functional characteristics of the PMP system and general and detailed design requirements for each component, 2) requirements related to site and environmental integration, and 3) detailed interface requirements. All systems beyond the PMP system interface at the tank riser and motive fluid connections are considered to be part of the balance of plant. 


\subsection{Pulsating Monitor Description and Performance}

This description of the pulsating mixer pump (PMP) is based on information obtained during the evaluation of the PMP in FY 1997 at Pacific Northwest National Laboratory during evaluation of Russian technologies identified for waste remediation. ${ }^{\text {a) }}$ The system tested consisted of the PMP and the supporting flow control unit.

\subsection{Pulsating Monitor}

The original PMP, shown in Figure 3.1, consists of an upright cylindrical reservoir, a footcheck valve, a working gas supply pipe, a discharge manifold, and jet nozzles. The gas supply pipe is plumbed to a control valve, which alternates the exposure of the line between a vacuum and air supply source. In operation, the waste is drawn into the reservoir through the foot-check valve when the supply pipe is valved to the vacuum source. The supply pipe is then pressurized with supply air; the pressurized air discharges the fluid out of the monitor reservoir back into the tank through the jet nozzles.

Only two jet nozzles were used during testing at PNNL; however, there are four ports for jets in the head. The preliminary drawings showed a fifth nozzle directed axially downward on the centerline of the monitor, but the port for that jet was not present on the test article.

The vacuum supply to the pulsating equipment was provided by an axial-jet eductor furnished with the equipment. A diesel-powered trailer compressor supplied compressed air to the pulsating monitor and the vacuum eductor. The eductor was supplied and specified by Integrated Mining Chemical Company as requiring $4 \mathrm{~m}^{3} / \min (141 \mathrm{cfm})$ of air delivered at approximately $480 \mathrm{kPa}$ gauge ( $70 \mathrm{psig}$ ) to produce $40 \mathrm{kPa}$ gauge $(5.8 \mathrm{psig}$ ) of vacuum. The air supply line to the eductor was at a pressure of $725 \mathrm{kPa}$ gauge (105 psig) and was throttled to obtain the desired vacuum line pressure. The actual air flow rate to the eductor was not measured. PNNL safety personnel conducted a noise survey of the eductor. The following sound levels, on the A-weighted scale ( $\mathrm{dB}(\mathrm{A})$ ), were obtained at various distances from the outlet of

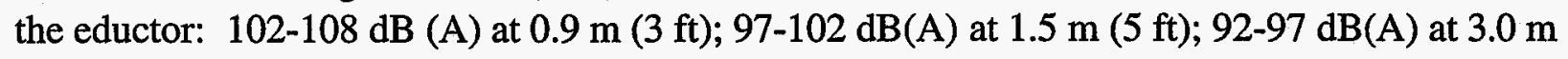
$(10 \mathrm{ft})$; and $92 \mathrm{~dB}(\mathrm{~A})$ at $6.1 \mathrm{~m}(20 \mathrm{ft})$.

a) Four systems were provided for evaluation: pulsating pump, pulsating mixing pump, hydro monitor, and hydroelevator. 


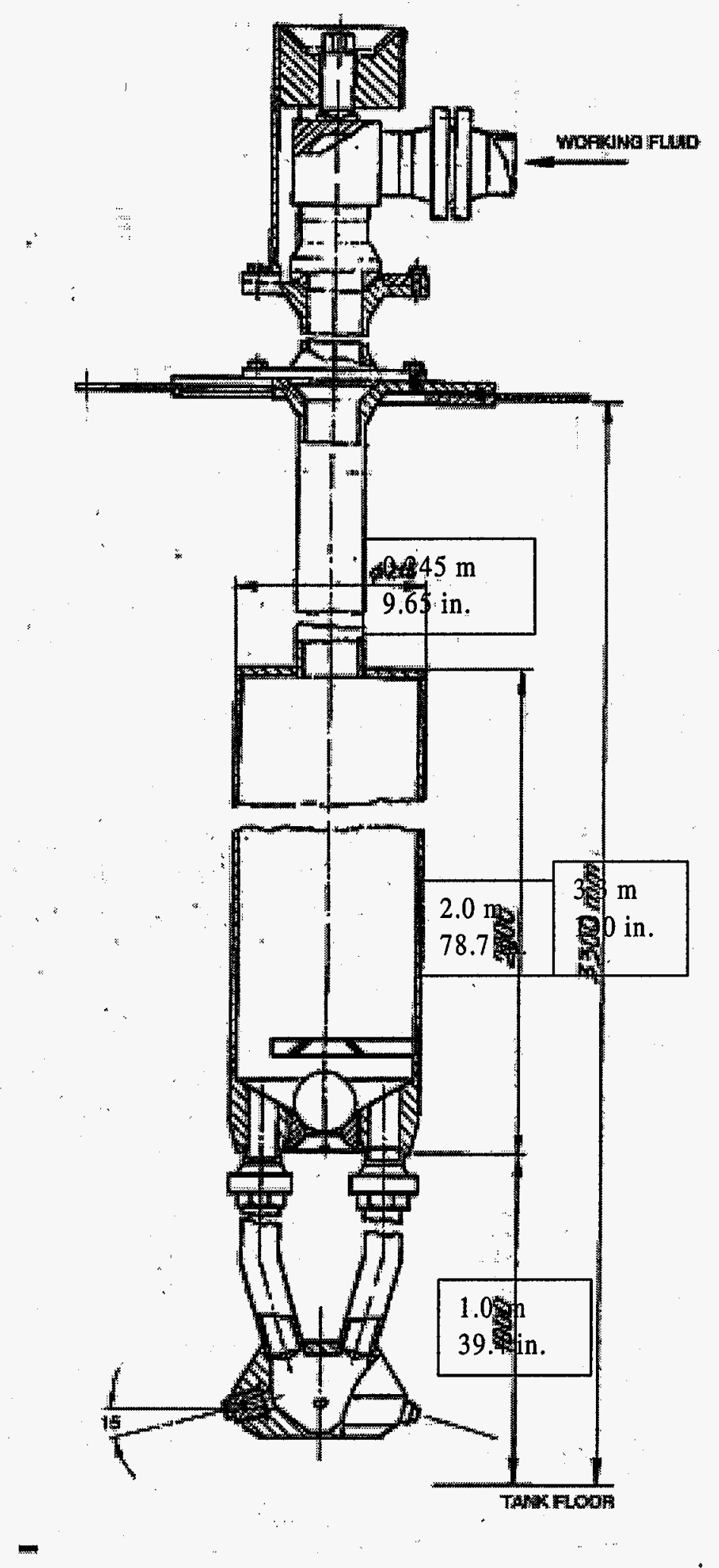

Figure 3.1 Pulsating Monitor Tested by PNNL 


\subsection{Pulsating Mixer Pump Demonstration at PNNL}

At PNNL, the operation of the PMP was demonstrated in a 5.7-m (18.75-ft) -diameter tank. ${ }^{\text {a) }}$ The PMP operation was visualized using medium grain sand $(1$ to $2.4 \mathrm{~mm})$ spread over the tank bottom and water as a supernatant liquid. The size of the sand was selected to be large enough so that the PMP jets would not suspend the sand when the system was operating at the control settings selected for the demonstration. The purpose of the sand was to provide flow visualization of the influence that the PMP jets have on the test tank floor. The PMP contained two diametrically opposed, 8-mm (0.31-in.) diameter nozzles

Two tests, tests 3 and 4, were conducted with the PMP remaining stationary (not rotating).

Test 3 was conducted with the nozzles oriented in a north-south direction. During Test 3 the period was 21 seconds and the vacuum and supply pressures were $77 \mathrm{kPa}$ absolute (11.1 psia) and $557 \mathrm{kPa}$ gauge ( $80.7 \mathrm{psig}$ ) respectively. The PMP was run for 9 minutes and then the cleared area on the tank floor was measured. The dimensions for the observed area of jet influence on the bottom of the tank are presented in Figure 3.2. The PMP was not located in the center of the tank.

The first jet pulse cleared the floor of sand out to a distance of approximately $1.5 \mathrm{~m}(5 \mathrm{ft})$ and on the second pulse to about $1.8 \mathrm{~m}(6 \mathrm{ft})$. After the first four pulses, the growth of the footprint slowed considerably. After nine minutes of run time the jets was still moving sand on the bottom of the tank causing the cleared area to grow at a slow rate.

For Test 4, the PMP was rotated $90^{\circ}$ so that one of the nozzles would erode a thick layer of sand. The pulse rate was maintained at 21 seconds, and the time average pressures were $78 \mathrm{kPa}$ absolute (11.4 psia) and 556kPa gauge ( $80.7 \mathrm{psig}$ ) for the vacuum and supply pressure, respectively. Test 4 was run for approximately four minutes. The dimensions for the cleared area created by the jet to the west of the PMP (i.e., through the thick layer of sand) are presented in Figure 3.2. A composite photograph of the bottom of the 1/4 Scale DST was taken at the completion of Test 4 and is displayed in Figure 3.3. The photograph was taken from the east side of the tank (i.e., north is to the right of the picture).

a) The details of the pulsating mixer pump demonstration at PNNL have been excerpted from the report entitled, Performance Evaluation of the Quarter-Scale Russian Retrieval Equipment for the Removal of Hazardous Waste, PNNL-11740, by CW Enderlin, OD Mullen, and G Terrones. 


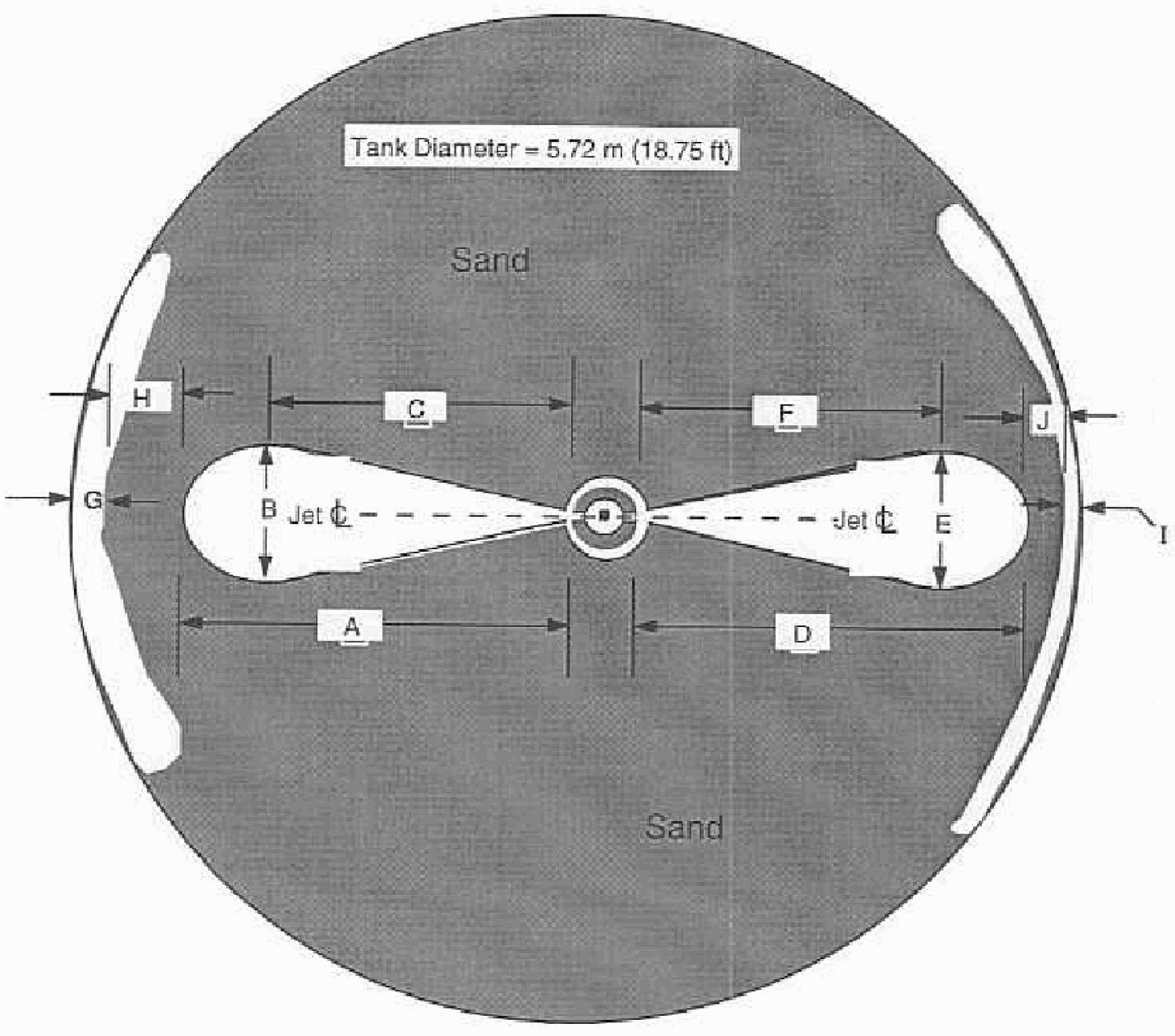

Test 3 Results

\begin{tabular}{lllllc}
\hline Dimension & m & in. & Dimension & m & in. \\
\hline A & 2.34 & 92 & F & $1.6-1.7$ & $63-66$ \\
B & $0.79-.81$ & $31-32$ & G & 0.20 & 8 \\
C & $1.57-1.60$ & $62-63$ & H & 0.25 & 10 \\
D & 2.59 & 102 & I & 0.08 & 3 \\
E & $0.76-0.79$ & $30-31$ & J & 0.08 & 3 \\
\hline
\end{tabular}

Test 4 Results

\begin{tabular}{llllll}
\hline Dimension & m & in. & Dimension & mi & in. \\
\hline A & 2.51 & 99 & H & 3 & 0.08 \\
B & 0.60 & 24 & G & 3 & 0.08 \\
C & $1.78-1.83$ & $70-72$ & & & \\
\hline
\end{tabular}

Figure 3.2 Diagram and Dimensions of Jet Fontprint created by Pulsating Monitor on Tank Floof. 
Figure 3.3 Composite Photograph of Flow Pattern Created in Sand by Pulsating Monitor at Completion of Test 4.

The PMP was not tested further because of time and budget constraints. The purpose of the demonstration was to provide an initial evaluation to determine whether the PMP technology merited further consideration for applications to the US DOE waste tanks and to provide insight for the development of a more extensive test matrix. 


\subsection{Gunite Tank and Site Description}

Gunite tanks W-8, W-9, and TH-4 have been identified as candidates for deployment of the pulsating mixer pump (PMP). The construction of these tanks is summarized below.

\subsection{South Tank Farm Tanks}

The tanks are each $15 \mathrm{~m}$ (50 ft) in diameter with a capacity of $640,000 \ell(170,000 \mathrm{gal})$ per tank. A cross-section of the general tank layout is shown in Figure 4.1. Details of the sloped floor are shown in Figure 4.2.

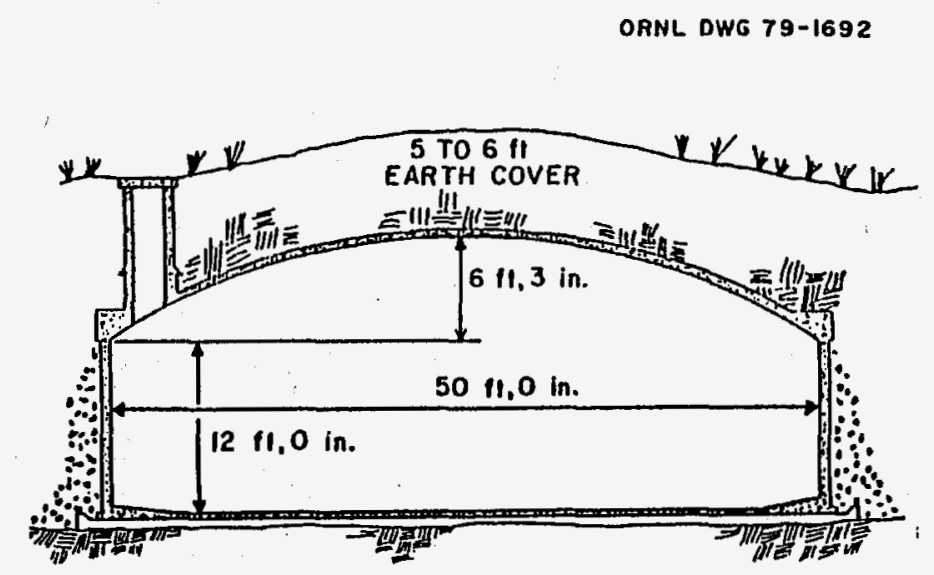

Figure 4.1 Gunite Tank Dimensions

The tanks were constructed out of sprayed cement slurry (Gunite process) which was sprayed against a lattice of integral reinforcing bars. The Gunite layering is shown in Figure 4.3. The original Gunite layer on the tank floor and walls was covered by a $6.3 \mathrm{~mm}(1 / 4-\mathrm{in})$ layer of asphalt and a $3.8 \mathrm{~cm}(1.5 \mathrm{in})$ inner layer of gunite. The walls were $19-\mathrm{cm}(7.5$ in.) thick. A leak detection system was installed in a French drain at the base of the tank outside wall. No double containment was installed. 


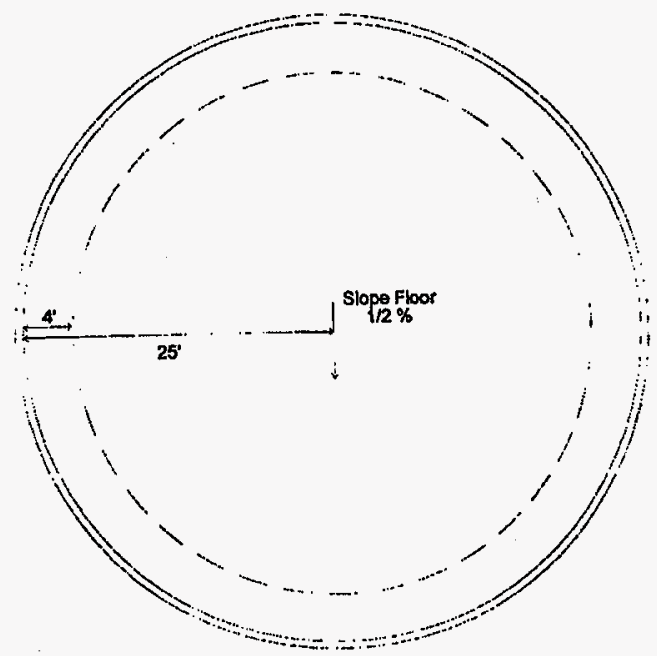

Figure 4.2 Slope of Gunite Tank Floor

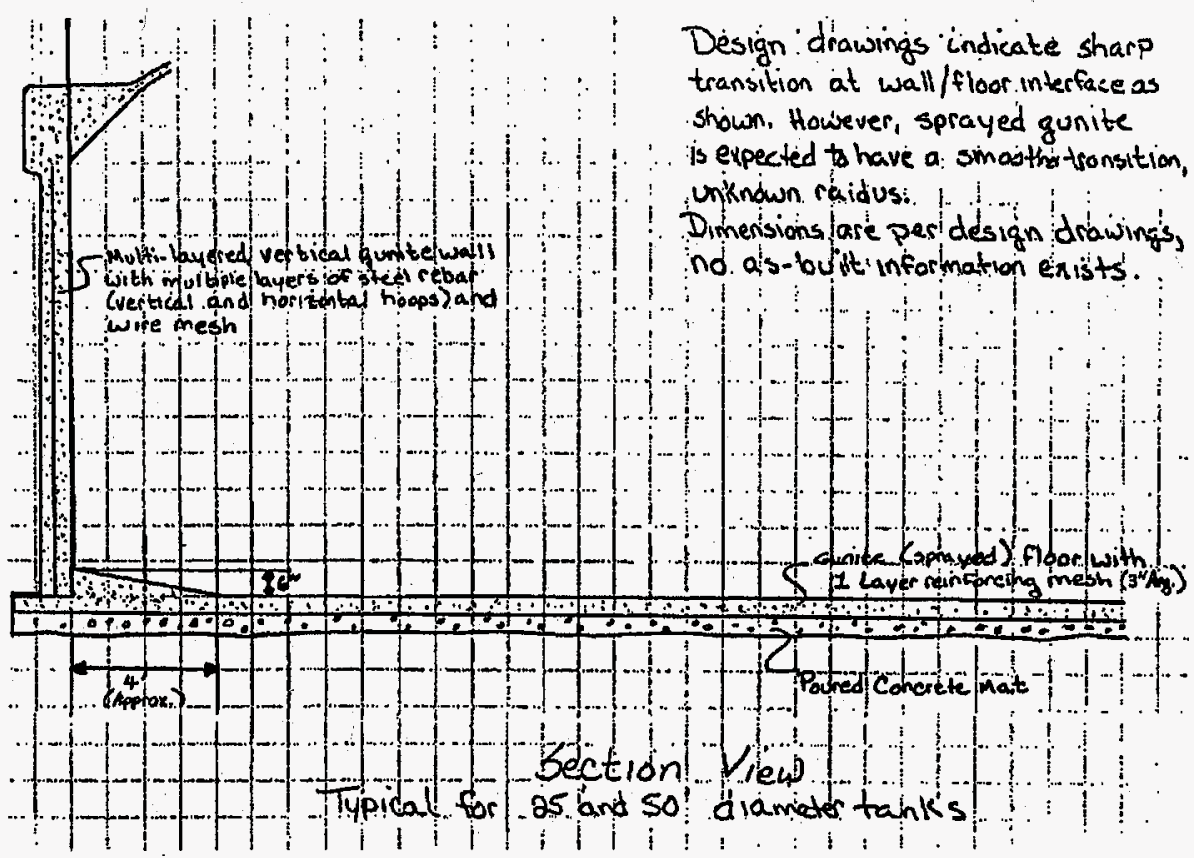

Figure 4.3 Gunite Tank Construction Details

\section{1}

The six tanks were installed in two rows of three tanks, each with a center-to-center spacing of $18.3-\mathrm{m}(60 \mathrm{ft})$ between tanks and between rows. 


\subsection{Tank TH-4}

Tank TH-4 is constructed using the same techniques as the STF tanks, only the overall tank dimensions are smaller. TH-4 is $6.1 \mathrm{~m}(20 \mathrm{ft})$ in diameter, with a total working capacity of 52,9961 (14,000 gal). Design information indicates a wall thickness of $15.2 \mathrm{~cm}$ (6 inches) and a $7.6 \mathrm{~cm}$ (3 inch) sprayed floor. It is expected that an asphalt layer and additional $3.8 \mathrm{~cm}(1.5 \mathrm{in})$ of gunite was added to the floor and walls as in the STF tanks. The tank has a vertical sidewall height of $2.0 \mathrm{~m}(6.5 \mathrm{ft})$.

\subsection{Risers}

The Gunite tank risers are nominally $34 \mathrm{in}$. outside diameter. The actual opening in the STF tank dome is either $59.7 \mathrm{~cm}$ ( $23.5 \mathrm{in}$.) or $78.7 \mathrm{~cm}$ (31 in.) depending upon when the riser was installed. All STF tanks have both size risers, but only the larger diameter risers will be present on TH-4. The PMP may be installed in any of the existing risers; the location has not yet been selected. Depending upon the performance of the PMP jets, the PMP may be deployed in several risers in each tank to ensure that waste is fully mobilized.

\subsection{Platforms}

A total of three service support platforms exist in the STF, each of which spans an entire tank. Two of the platforms are movable and are installed at the tanks undergoing equipment deployment. The pulsating mixer pump (PMP) hardware will be supported by a service platform during deployment. Tanks W-8 and W-9 are each spanned by movable platforms. The distance from the tank floor to the platform level is nominally

$8.7 \pm 0.3 \mathrm{~m}(28.5 \pm 1 \mathrm{ft})$ for the STF tanks. The PMP system design (including wind and seismic loading) will utilize the existing platforms. A small platform will be provided for tank TH-4, if used. The platform will be sized to accommodate the PMP, and maintain the same position relative to the tank riser as the STF platforms. The distance from the tank floor to the platform level is nominally $5.6 \pm 0.3 \mathrm{~m}(18.5 \pm 1 \mathrm{ft})$ for tank TH-4.

The STF platform dimensions and construction details are shown in a series of engineering drawings provided by ORNL These drawings are summarized in Table 4.1.

\subsection{Utilities}

The process utilities provided at the South Tank Farm include 
- Electricity - Three phase $\mathrm{AC}$ power at 220 and $480 \mathrm{Volts}, 60 \mathrm{~Hz}$

- Compressed air - Plant utility air (typically 550 to $620 \mathrm{kPa}$-gage [80 to $90 \mathrm{psig}$ ]). This air is not instrument quantity; however, some dryers are available to supply small quantities of dried air.

- Process water - supplied from a 4-in. header via 2-in. process supply lines, usually 480 to $550 \mathrm{kPa}$-gage (70 to $80 \mathrm{psig}$ ) available.

Similar utilities will be provided at tank Th-4 if selected for deployment of the PMP. 
Table 4.1 List of Engineering Drawings

\begin{tabular}{|c|c|c|c|}
\hline Drawing Number & Project & Title & Comments \\
\hline A3E020539A001 Rev A & $\begin{array}{l}\text { Gunite \& Associated } \\
\text { Tanks }\end{array}$ & $\begin{array}{l}\text { Platform Modifications } \\
\text { Plan and Sections }\end{array}$ & $\begin{array}{l}\text { Shows top of platform for } \\
\text { tanks W-7 and W-8 }\end{array}$ \\
\hline A3E020539A002 Rev A & $\begin{array}{l}\text { Gunite \& Associated } \\
\text { Tanks }\end{array}$ & $\begin{array}{l}\text { Platform Modifications } \\
\text { Plan and Sections }\end{array}$ & $\begin{array}{l}\text { Shows Column length } \\
\text { extensions for tanks }\end{array}$ \\
\hline A3E020539A003 Rev A & $\begin{array}{l}\text { Gunite \& Associated } \\
\text { Tanks }\end{array}$ & $\begin{array}{l}\text { Platform Modifications } \\
\text { Plan and Sections }\end{array}$ & $\begin{array}{l}\text { Shows prefabricated stairway } \\
\text { schedule and top of platform } \\
\text { grating elevation for tanks }\end{array}$ \\
\hline A3E020539A004 Rev A & $\begin{array}{l}\text { Gunite \& Associated } \\
\text { Tanks }\end{array}$ & $\begin{array}{l}\text { Platform Modifications, } \\
\text { Key Plan, Notes, } \\
\text { Sections and Details }\end{array}$ & $\begin{array}{l}\text { Show s platform locations for } \\
\text { tanks }\end{array}$ \\
\hline A3E020539A005 Rev A & $\begin{array}{l}\text { Gunite \& Associated } \\
\text { Tanks }\end{array}$ & $\begin{array}{l}\text { MLDUA Base Plate } \\
\text { Relocation and Details }\end{array}$ & Not applicable \\
\hline A3E020539A006 Rev A & $\begin{array}{l}\text { Gunite \& Associated } \\
\text { Tanks }\end{array}$ & $\begin{array}{l}\text { Additional Risers for } \\
\text { South Tank Farm }\end{array}$ & $\begin{array}{l}\text { Shows details and location of } \\
34-\text { and } 12 \text {-in.-diameter } \\
\text { risers }\end{array}$ \\
\hline & & & \\
\hline $\begin{array}{l}\text { GAAT-STF SK01 Rev } \\
\text { B. }\end{array}$ & $\begin{array}{l}\text { Gunite \& Associated } \\
\text { Tanks }\end{array}$ & Operations Site Plan & $\begin{array}{l}\text { Show s plan view of South } \\
\text { Tank Farm Site and } \\
\text { equipment }\end{array}$ \\
\hline
\end{tabular}




\subsection{Waste Properties}

The tanks contain radioactive chemical waste that consists of settled sludge covered by a layer of aqueous supernatant liquid with a vaporous air space above the liquid. Current best estimate data are summarized in Table 5.1. These data are presented to provide an idea of the volume and type of waste contained in the tanks.

Table 5.1 Gunite Tank Contents

\begin{tabular}{|c|c|c|c|c|c|c|}
\hline $\begin{array}{l}\text { Tank } \\
\text { No. }\end{array}$ & $\begin{array}{l}\text { Total } \\
\text { Tank } \\
\text { Depth, ft }\end{array}$ & $\begin{array}{l}\text { Liquid } \\
\text { Depth, ft* }\end{array}$ & $\begin{array}{l}\text { Sludge } \\
\text { Depth, ft }\end{array}$ & $\begin{array}{l}\text { Liquid } \\
\text { Temperature,C }\end{array}$ & $\begin{array}{l}\text { Sludge } \\
\text { Vol, gal }\end{array}$ & $\begin{array}{l}\text { Sample } \\
\text { Dose Rate, } \\
\text { count/min }\end{array}$ \\
\hline $\begin{array}{l}\text { TH- } \\
4\end{array}$ & 15.0 & 4.0 & 2.5 & & 5,500 & \\
\hline W-8 & 25.0 & 10.0 & 0.67 & 19.3 & 10,300 & $\begin{array}{r}45 \\
46 \\
180\end{array}$ \\
\hline W-9 & 25.0 & 4.0 & 2.5 & 18.3 & 36,300 & $\begin{array}{c}36 \\
1200 \\
\end{array}$ \\
\hline
\end{tabular}

${ }^{*}$ Liquid depths are presented for information and can be increased or decreased as necessary.

Tank W-9 has been used as the receipt tank for waste remediation operations prior to waste transfer out of the tank farm, and the estimated current waste volume is given. Tank W-9 is slated to receive additional consolidated waste, and waste transfers out of the tank are scheduled to begin by the third quarter of FY-1999.

Tank waste sampling and characterization data is very limited. The following information is "best estimate" and should be used conservatively (Martin Marietta Energy Systems).

The solid waste is non-heat generating, insensitive to impact, rubbing or abrasion. The $\mathrm{pH}$ ranges from 7 to 11 . Organic compounds (not identified, but including $\sim 100 \mathrm{ppm}$ concentrations of "light hydrocarbon", up to $700 \mathrm{ppm}$ tri-butyl phosphate, and less than $10 \mathrm{ppm}$ each of anthracene, fluoranthene and pyrene)may be expected in the wastes, as are nitrates, phosphates and sulfates.

The solid waste is a mixture of silt, clay, pasty particles, some crystallized solids which may have formed during storage, lumps of Gunite which may have eroded from the tank walls, and miscellaneous debris such as plastic bags, coveralls, and metal cans. Some waste forms may 
be highly abrasive. Bulk slurry density ranges from $1.0 \mathrm{~g} / \mathrm{ml}$ to $1.47 \mathrm{~g} / \mathrm{ml}$ have been measured in samples. Solids density may exceed $2.0 \mathrm{~g} / \mathrm{ml}$. Concentration in the undisturbed sludge of up to approximately 45 weight percent solids is expected. Particles ranging from less than 10 micron to approximately $3 / 8$ inch may require mobilizing and removal.

The temperature ranges from $4^{\circ}$ to $27^{\circ} \mathrm{C}\left(40^{\circ} \mathrm{F}\right.$ to $\left.80^{\circ} \mathrm{F}\right)$ and radiation emissions are estimated to range from $100 \mathrm{mR} / \mathrm{hr}$ to $50 \mathrm{R} / \mathrm{hr}$, with point sources in excess of $150 \mathrm{R} / \mathrm{hr}$.

The liquid waste is primarily water, containing some soluble material from the tank waste. The density of the liquid is in the range of $0.99 \mathrm{~g} / \mathrm{ml}$ to $1.06 \mathrm{~g} / \mathrm{ml}$ and the viscosity is approximately equal to that of water. A thicker transition phase close to the waste surface may be present along with a density gradient. The $\mathrm{pH}$ ranges from 7 to 11 and the conductivity from 10 to $20 \mathrm{mho} / \mathrm{cm}$. Organic compounds (TOC) are present in concentrations of 200 to $8500 \mu \mathrm{g} / \mathrm{g}$. Note that tank W-10 contains PCBs $>2 \mathrm{ppm}$ but $<10 \mathrm{ppm}$.

The vapor space contains air with vapors emitted from the supernatant liquid, which are nonflammable and non-explosive. Within the vapor space of the tanks the pressure may vary from $498 \mathrm{~Pa}$ to $0 \mathrm{~Pa}$ - gage ( -2.0 to 0 inches $\mathrm{H} 20$ - gage). The relative humidity and temperature range from $4 \%$ to $100 \%$ and from 4 to $27\left(\mathrm{C}\left(40^{\circ} \mathrm{F}\right.\right.$ to $\left.80^{\circ} \mathrm{F}\right)$ respectively. 


\subsection{Pulsating Monitor Components, Functions, and Requirements}

The pulsating mixer pump (PMP) system is comprised of the following components: PMP, control system, tank riser interface (TRI), containment/deployment system, and decontamination system. The last three items were not included on the system tested at PNNL in FY 1997. They are required for the ORNL system because the PMP is to be deployed and operated remotely in a radioactive environment.

\subsection{Pulsating Monitor}

The primary function of the PMP is to mobilize solids in Gunite tanks filled with sludge, settled solids, and supernatant liquid. The secondary function of the PMP is to keep the solids in suspension while the waste is pumped from the tank.

\subsubsection{Functions}

The PMP must be designed to:

- Be deployed in the tank through existing risers, which may have a minimum opening of $59.7 \mathrm{~cm}(23.5 \mathrm{in})$ without riser sleeve and $57.2 \mathrm{~cm}(22.5 \mathrm{in})$ with steel sleeves.

- Withstand and operate in a tank waste environment of: temperature, $4^{\circ}$ to $60^{\circ} \mathrm{C}\left(40^{\circ}\right.$ to $140^{\circ} \mathrm{F}$ ); radiological exposure, to $150 \mathrm{R} / \mathrm{hr}$; and $\mathrm{pH}, 7$ to 12 . The possible waste properties that may be encountered are specified in Section 5.0.

- Mobilize tank waste $e^{a}$ from the tank floor using fluid jets that provide $360^{\circ}$ coverage of the tank floor. The PMP must be operable in both a sweeping and stationary mode.

- Be deployed and operate over a range of sludge heights from 0 to $0.9 \mathrm{~m}(0$ to $3 \mathrm{ft})$ and supernatant liquid heights of 0.15 to $3.0 \mathrm{~m}(0.5 \mathrm{ft}$ to $10 \mathrm{ft})$.

- Operate over a range of waste types (particle sizes, concentrations, densities, and mixture viscosities) as specified in Section 5.0.

- Operate at prescribed distances above the tank floor in tanks with riser elevations (top of riser) above the tank floor ranging from 7.31 to $7.93 \mathrm{~m}$ ( 24 to $26 \mathrm{ft}$ ) or 4.3 to $4.9 \mathrm{~m}$ (14 to $16 \mathrm{ft}$ ).

- Operate at distances of 5 to $61 \mathrm{~cm}$ (2 to 24 in) above the tank floor.

- Operate for $1000 \mathrm{hr}$ over a two-year span without scheduled maintenance being performed to the in-tank components of the system.

\footnotetext{
a) The waste physical property data (supernate density, solids density, particle size, concentration, and viscosity) can be used to establish the requirements for the pulsating mixer pump.
} 
- Operate at ambient conditions of $-18^{\circ}$ to $49^{\circ} \mathrm{C}\left(0^{\circ}\right.$ to $\left.120^{\circ} \mathrm{F}\right)$ and $100 \%$ relative humidity and withstand storage at ambient conditions of $-29^{\circ}$ to $49^{\circ} \mathrm{C}\left(-20^{\circ}\right.$ to $\left.120^{\circ} \mathrm{F}\right)$ and $100 \%$ relative humidity, condensing.

- Operate in an outdoor installation exposed to full sun and weather.

\subsubsection{Design Considerations}

There are tradeoffs to be considered and documented during system design. In an ideal system, the period of operation should not be a factor in determining the flow rate. A highfrequency operation delivering a small volume per cycle will be as effective as a low-frequency operation pumping a large volume per cycle. In an actual system, there are losses associated with the fluid flow and the opening and closing of the valves. There are also losses associated with pressurizing and evacuating the PMP reservoir. During testing at PNNL, the estimated percent of the reservoir volume used was 25 to $40 \%$. If the reservoir was completely filled with liquid during a cycle, then the initiation of the supply air results in the fluid being evacuated without having to first pressurize a rarefied volume of the reservoir. Using only a fraction of the reservoir volume results in a large volume of air being conveyed without supplying any work to the system.

The effect of slurries containing large particles (those with settling velocity of the same order of magnitude as the fluid velocities within the system) must be considered when optimizing the system. Large particles will have velocities that differ from those of the liquid phase and there are additional losses resulting from accelerating the particles with each pulse. Several long pulses will be more efficient at transferring particles through the jet nozzle compared to a higher frequency pulse rate. Particles may accumulate around the check valve and cause problems during the discharge phase of the cycle.

Fluid entering the monitor will experience the highest velocity at the initiation of the fill portion of the pumping cycle, after which it will continue to decrease as the fluid level within the reservoir increases. This is due to the change in hydrostatic head resulting from the difference between the fluid levels inside and outside of the reservoir. Maximizing the ratio of reservoir volume to liquid elevation, therefore, can reduce the fill time. This can be accomplished by increasing the ratio of the reservoir diameter to the reservoir height or by reclining the reservoir. The size and shape of the reservoir should be optimized so that a majority of the volume is utilized for the pumping process. Reducing the pressure drop across the inlet check valve can also decrease the fill time.

\subsubsection{Components}

The PMP system includes the pressure vessel and piping, check valves, strainer, fresh water back-flush system, nozzles, rotation system, and containment seal/isolation system. 


\subsubsection{Requirements}

The following requirements must be met by the design and operating procedures for the PMP system.

\subsubsection{Deployment and Operation}

- The maximum diameter of components inserted through the riser and riser sleeve must not exceed $57.1 \mathrm{~cm}$ (22.5 in.).

- The system must operate in liquid levels ranging from 0.15 to $3.0 \mathrm{~m}(0.5$ to $10 \mathrm{ft})$.

- The PMP must mobilize solids in a $360^{\circ}$ arc around the base of the system.

- Provisions must be made to mobilize solids beneath the PMP.

- Large particles must be prevented from entering the check valve, and a method to rinse/back flush the check valve, screens, and internal components with clean process water must be provided. A method must also be provided for removing internal blockages.

- The PMP is to be designed so that solids and/or contamination do not accumulate inside system components.

- The bottom surface of the PMP must be flat and horizontal to avoid damage to the tank floor. The bottom of the PMP shall be sized so that a concentrated load limit of $5170 \mathrm{kPa}$ (750 psi) on the tank floor is not exceeded. The flat surface area shall be large enough to minimize the risk of penetrating the tank floor and prevent damage from dynamic forces created by PMP operation. Higher loads on the tank floor will require prior approval from the facility manger.

- The system design shall allow the PMP to be installed, operated, decontaminated, and removed from the waste tanks using practices and procedures, which conform and are acceptable to current ORNL tank farm standards. The design of the PMP must accommodate current bag out procedures employed at ORNL.

- Deployment and withdrawal of the PMP is to be accomplished with a single pick (i.e. only one hoist or crane shall be necessary).

- The location of the center of gravity for the PMP will result in the PMP hanging vertically when suspended for deployment.

- The bottom of the tank risers contains sharp edged lips. In-tank surfaces of the PMP are to be vertical, tapered, rounded, or shrouded so that the PMP can be removed from the tank without interfering with the tank riser (i.e. catch on the riser lip). The outer profile of the PMP is to be designed so that it aids in re-centering the PMP within the riser should it contact the riser during deployment or withdrawal.

- During deployment or removal the longitudinal axis of the PMP is to remain perpendicular with the deck of the support platform. Gravity will be the only force applied to the PMP for insertion into the waste. Therefore, the design and operational procedures must account for any effects of buoyancy due to components and piping being empty at the time of deployment or removal. 
- The PMP must not discharge air from the tank to the external environment.

- The maximum air consumption inside the tank will be limited by a passive flow restriction device provided and installed by ORNL such that the aerosol generation rate within the tank during operation or failure of the PMP shall not exceed tank safety limits. This will avoid additional components being designated safety related. The actual maximum air flow may be bound by either the aerosol generation rate or the capacity of the tank off gas system, whichever is less.

- The orientation of the nozzles is to be indicated on the PMP and observable upon visual inspection while the PMP is deployed in the tank.

- The initialization of the reference frame used by the control system to indicate nozzle orientation needs to be marked on the PMP and observable when the PMP is deployed.

- The PMP is to interface with the TRI System.

\subsubsection{Containment}

- Ensure contaminated liquids and aerosol can not escape from the tank during operation or while idle. During a loss of the control system or electrical power, the system must provide and maintain tank containment. The loss of air pressure or supply water pressure needs to result in the sealing of all flow paths out of the tank.

- Ensure that all radioactively contaminated gases or air can not escape from the tank via the TRI/PMP equipment and/or riser interface even in the case of the tank becoming pressurized to $14 \mathrm{kPa}$ gage ( $2 \mathrm{psig}$ ).

- The maximum airflow into the tank must not produce a positive pressure inside the tank or riser space. The maximum flow rate is $5.7 \mathrm{~m}^{3} / \mathrm{min}\left(200 \mathrm{ft}^{3} / \mathrm{min}\right)$. The final limiting factor for flow may be slightly lower based on the estimated aerosol generation rate for the PMP design or measured ventilation flow for the actual tank selected for deployment.

\subsubsection{Decontamination}

- The in-tank portion of the PMP shall be designed to minimize decontamination efforts. Cracks, crevices, depressions, or enclosed voids which can entrap contaminated waste, that will not drain, or that can not be cleaned by the jets from a spray ring or by internal flushing will be minimized to the extent possible.

- During decontamination the PMP must withstand water spray from jets at a pressure of $3450 \mathrm{kPa}(500 \mathrm{psig})$ with a flow rate of $61 / \mathrm{min} /$ nozzle $(1.5 \mathrm{gpm} / \mathrm{nozzle})$.

\subsubsection{Maintenance}

- All out of tank components must be serviceable without removing the PMP from the riser.

- The PMP must operate for $1000 \mathrm{hr}$ over a 2 year span without scheduled maintenance being performed to the in-tank components of the system. The PMP will be designed to 
allow for manual servicing and replacement of parts using common glove-box techniques employed at ORNL.

- Mechanical guards will be designed and installed over all moving parts exposed above the riser to prevent injury of personnel or damage to cables, leads, hoses etc.

- All hoses and hose connections are to be protected from operational wear. The contact of hoses that experience oscillatory motion with other components should be avoided.

- Exposed hoses will be constructed of UV resistant material suitable for a two-year operational life in a fully exposed outdoor installation.

- The PMP system will include provisions to allow for mechanical lockout of systems/components.

- The PMP needs to break down into vertical lengths for ease of shipment and handling and to more readily accommodate various tank configurations. The assembly of the PMP is to utilize flanged connections with no field welding being required. The capability will exist to shorten or lengthen the overall length of the PMP to accommodate future tanks by fabricating and inserting spool pieces of varying lengths. The top and bottom spool pieces are to be as short as possible to provide maximum versatility by ensuring that in the future the PMP will fit in the shallowest tank possible. The mid-section spool pieces for the current design being addressed need only meet the length requirements for the Gunite tanks.

- The selection of the nozzle diameters and operating conditions and the operating and maintenance instructions are to be documented and provided to ORNL.

\subsection{Control System}

The primary functions of the control system are 1) to permit the PMP system to operate optimally over a range of operating conditions 2 ) to provide automatic shut down in case an outof-specification condition occurs 3) to allow remote operation of the system from either the inside of the ORNL Gunite Tank Farm control shed, which has a maximum distance from the tank risers of $300 \mathrm{ft}$, or the riser site.

\subsubsection{Functions}

The PMP control system must be designed to:

- Continuously monitor and record system operating conditions (pressures for both rarefaction and pressurization cycles, cycle time, rotation, indication of strainer blockage, and nozzle orientation).

- Provide a method to balance the fluid transfer during the charge and discharge portions of the cycle so that no fluid accumulates in the vessel over time.

- Provide stable operation under steady state and transient scenarios. Mobilization could be considered transient, as could concurrent mixing with waste transfer from the tank. Mixing without waste transfer could be considered a steady state operation. 
- Shut down the system when an out-of-specification condition occurs (over pressurization or a loss of containment).

- Interlock the system to automatically shut down operations introducing compressed air into the tank upon receipt of a loss of tank vacuum signal. (loss of vacuum signal provided by ORNL).

- Provide system control and monitoring at the riser or in the ORNL Gunite Tank Farm control room.

- Ensure the air flow rate does not exceed the maximum allowable, based on aerosol generation rate calculations,. for tank safety conditions (may be restricted by passive device installed by ORNL in the air supply piping rather than control system).

- The system should be designed to interface with existing GAAT equipment and be designed for remote, outdoor operation.

- Provide all hardware and software necessary for stand alone operation independent from existing GAAT control systems.

\subsubsection{Design Considerations}

Under steady state operating conditions the PMP should require minimal manual intervention. However, if changes do occur in the operating conditions (e.g., changes in the height of the tank fluid, in the concentration of the tank slurry, or fouling of the check valves or nozzles) then adjustments must be made to rebalance the system. If the changes are a continual occurrence, continual or periodic action will be required.

The system operation relies on the fill and evacuation phases of the pump cycle being balanced with regards to the flow rate. What is drawn into the reservoir must be discharged. If the system is out of balance, then the volume of fluid in the reservoir will either incrementally decrease, eventually resulting in the discharging of air to the tank, or incrementally increase, resulting in fluid being drawn into the vacuum line.

ORNL will provide site information identifying

- The location of the control system and the E-stop (emergency shut down) switch.

- Comments and recommendations on proposed local displays and displays in the control room.

\subsubsection{Components}

The control system includes remote and on site control, instrumentation, interfaces, control valves and manifold, and a PC computer and accompanying software.

\subsubsection{Requirements}

The design and operation of the control system must meet the following requirements. 
- The maximum distance between the remote control room and the PMP is $91.4 \mathrm{~m}$ ( $300 \mathrm{ft}$ ). The control system will include a short cable for local control within $45.7 \mathrm{~m} \mathrm{(50 \textrm {ft } ) \text { and }}$

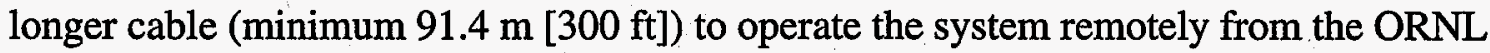
Gunite Tank Farm control room. The control functions used at the riser and the control room will be identical. Only one location at a time will have the control system connected (i.e., only one $\mathrm{PC}$ required).

- An emergency shut down 'E-stop' will be provided at the control point.

- Real-time process update and control feedback to continuously maintain a desired operating condition will be provided.

- Radioactive waste will be contained within the confines of the tank to which the PMP is installed. Liquid will not be removed from the tank and no air or gases will discharge from the tank to the external environment.

- The control system will be PC based, modular and easily maintained. The system will be password protected to prevent inadvertant modification, and designed such that a qualified person can maintain or modify using only the information provided with the system (operating documentation, design drawings, etc.).

- Independent control of the rarefaction and discharge pressures will be possible.

- The orientation/position of the nozzles will be indicated visually at the riser as a minimum, and may be displayed and recorded by the control system.

- The rarefaction pressure, discharge pressure, cycle time, and rotation speed will be displayed and recorded.

- The control system will provide continual operation at user specified conditions, allow for changes to be made to the user specified operating conditions without shutting down the system, and shut down the system in the case of off-normal events or when out of range conditions are encountered. The control system will display and record identification of the parameter triggering the system shut down. (E.g. no change in vessel level, out of range fill or drain time, etc.).

Back flushing/rinsing of the PMP components will be possible either remotely or manually at the riser (ORNL will consider manual-only capability to simplify system).

- The PMP system will include check valves to prevent reverse flow to air or fresh water supply lines.

- Operation of the system from the ORNL Gunite tank farm control room will be possible. The control functions used at the riser and the control room will be identical. Only one location at a time will have the control system connected (i.e., only one PC required).

\subsection{Tank Riser Interface System}

The primary function of the tank riser interface (TRI) system is to provide an interface between the PMP and the tank riser, the service support platform, site utilities (electrical, air, and 
water), and the control system. The tank riser interface system will provide a support structure for the out of tank valves and will include a decontamination spray ring. The system will also provide a dust cover, which will permit access to any out-of-tank components requiring routine maintenance.

\subsubsection{Functions}

The TRI system must be designed to:

- Provide lifting lugs for crane deployment of the TRI system and the PMP.

- Limit the amount of human exposure to the load during lifting and rigging operations and eliminate any need for work beneath a suspended load.

- The deployment system supported by the TRI must be adjustable to accommodate insertion depths for the PMP of 5 to $61 \mathrm{~cm}$ ( 2 to 24 in) above the tank floor, using manual operation, and without breaking containment. The distance from the top of the risers to the tank floor ranges from 7.31 to $7.93 \mathrm{~m}(24$ to $26 \mathrm{ft})$ for tanks W-8 and W-9 or 4.3 to $4.9 \mathrm{~m} \mathrm{(14}$ to $16 \mathrm{ft}$ ) for tank TH-4. The deployment mechanism will not include any components that will force the PMP into the tank floor at a loading exceeding 750 psi.

- Interface with the existing service support platforms which have a square opening over the riser approximately $1.3 \mathrm{~m}$ (52 in.) wide which is centered over the riser within \pm 1 in.

- Interface with the tank risers which have an outside diameter of $86 \mathrm{~cm}$ (34 in.), inside diameters ranging from 59.7 to $78.7 \mathrm{~cm}$ (23.5 to $31 \mathrm{in}$.), and the top of which is $106.7 \pm$ $1.3 \mathrm{~cm}$ ( $42 \pm 0.5 \mathrm{in}$.) below the top of the deck of the service support platform.

\subsubsection{Design Considerations}

The TRI must provide for the adjustment of the PMP elevation when interfacing with risers at varying elevations above the tank floor and during remediation activities with the PMP deployed. Operational height adjustments will not be required while the PMP is running. Height adjustments will be to achieve discrete elevations at which prolonged operation will occur.

The PMP will rotate (oscillate) and be connected to the control valves by hoses. The support structure for the control valves should be designed and positioned to avoid interference with the rotation of the PMP and limit stress and wear on the hose and associated connections.

The dust cover could be designed to meet the requirement of a mechanical guard over all out of tank moving parts with the potential to cause bodily injury or equipment damage.

To meet the requirement of a single pick for deployment and removal of the PMP, a cradle/support device will have to be designed and fabricated to accompany the TRI. Any support mechanism will have to accommodate the containment bag. 


\subsubsection{Components}

The TRI system consists of the riser interface, lifting lugs for the TRI and the PMP, the service support platform interface, the control valve support structure, the dust cover, height adjustment system for the PMP, and out-of-tank support structure for the PMP.

\subsubsection{Requirements}

The following requirements must be met

- The design of the system will allow the TRI to be installed, operated, and removed from the service support platform using practices and procedures which conform and are acceptable to current ORNL tank farm standards

- Deployment and withdrawal of the TRI is to be accomplished with a single pick (i.e. only one hoist or crane shall be necessary). Components will be designed such that the PMP and TRI can be removed as a singal unit that does not require disassembly when moving between tank risers.

- The TRI will ensure a load limit of $8900 \mathrm{~N}$ (2000lbs) on the riser is not exceeded.

- The containment system is to include a tank riser sleeve to ensure smooth insertion surfaces and channel decontamination water and other liquids into the tank.

- The height adjustment of the PMP will be maintained in the event of a loss of power.

- Support equipment must be provided which allows the PMP to be stowed in a horizontal mode when removed from the tank.

- The out-of-tank support equipment must accommodate the single pick requirement during rigging/lifting operations, be adjustable to a level setting, provide a pivot point for rotating the PMP from a vertical to horizontal orientation using a crane. The equipment must also support the PMP in a horizontal position by the mounting flange and the vessel, and accommodate and avoid damaging the containment bag.

- The TRI will provide a secure attachment to the platform steel without impacting it's ability to support other equipment following removal of the PMP. Any additional structural steel required will be provided as part of the system.

\subsection{Decontamination System}

The function of the decontamination system is to remove surface contamination from the intank components of the PMP prior to the removal of equipment from the tank. Process water or other decontamination fluid commonly used at ORNL may be used for system decontamination. Internal decontamination will be accomplished by the fresh water back-flushing system of the PMP. 


\subsubsection{Requirements}

The decontamination system must be designed to:

- Be remotely operated.

- Remove the bulk of the contaminants from the exterior of the PMP.

- Ensure removed contaminants and decontamination fluid remains within the tank. This may be accomplished by performing the decontamination within the tank, or designing the TRI, decon module, and riser sleeve to funnel liquid and removed contaminates back to the tank.

- Process water at line pressure (approximately $550 \mathrm{kPa}$ [80 psi]) will be provided by ORNL. If additional pressure is required, a motive source will be provided with the PMP system.

- All components (hoses, nozzles, fittings, etc) will be designed for the maximum decontamination supply pressure. 


\subsection{System Requirements}

This section defines the system requirements for the pulsating mixer pump (PMP) system

\subsection{Codes and Standards}

The pulsating mixer pump (PMP) and all associated components must be designed and constructed to comply with good engineering practice and appropriate, applicable codes and standards.

\subsubsection{Facility Status}

The PMP system is an assembly of temporary outdoor equipment and shall not be classified as, nor have to meet the requirements of a permanent facility.

\subsubsection{Piping}

The piping shall be designed and constructed to meet or exceed applicable technical requirements for the intended use as defined in ANSI/ASME B31.3 Chemical Plant and Petroleum Refinery Piping per equivalent standards with the intent to meet current ORNL practices. All piping will under go pressure testing as part of the acceptance test. Piping designed and fabricated in the US (ex decontamination system piping) will be fabricated and tested per requirements of ASME B31.3.

Flanged connections may be used on all piping connections. Welding will be per applicable, national codes and standards and in compliance with section 9.4 of this document. No field welds are allowed.

Piping will be identified with permanently attached labels indicating, as a minimum, media and normal direction of flow.

\subsubsection{Pressure Vessel Construction}

Pressure vessels shall be designed and constructed to meet or exceed applicable technical requirements for the intended use as defined in the ASME boiler and pressure vessel code per equivalent standards with the intent to meet current ORNL practices. All pressure vessels will under go pressure testing as part of the acceptance test.

Welding will be in compliance with the applicable national codes and standards and per section 9.4 of this document. No field welds are allowed. 


\subsubsection{Valves}

All valves will be designed, fabricated and installed to applicable national codes and standards.

Valves and materials of construction will be selected for compatibility with the intended service.

All automatic/remote-operated valves will include a position indicator integral to or mounted directly on the valve body. All valves will include the capability for local, manual operation.

Each valve will be identified by a unique number on design drawings and have a corresponding label or tag permanently attached to the valve body.

\subsubsection{Electrical Components}

Electrical components and workmanship must be manufactured, installed, and completed in accordance with the National Electrical Code, NFPA 70. Materials and equipment will be approved by UL whenever standards have been established for the application.

\subsubsection{Additional Instructions}

Materials compatible with the conditions defined in Section 5 and the intended use shall be selected.

Stainless steel surfaces shall be finished to standard manufacturing finish suitable for the intended application. Mild steel surfaces will be prepared to standard manufacturing finish suitable for the application. All external mild steel surfaces will be cleaned and painted with a commercially available paint applied per the manufacturer's instructions. A compatible primer will be applied per the paint manufacturer's instructions unless self-priming paint is used. All paint and coatings are to be lead free.

\subsection{Operations}

\subsubsection{Tank Pressure}

The PMP shall not create a positive pressure within the tank as measured relative to the outof-tank ambient pressure. This is applicable during normal operation and during any identified failure modes. An interlock with the ORNL tank pressure signal will automatically shut down functions which can introduce compressed air into the tank if a loss of negative pressure is indicated by the ORNL signal.

\subsubsection{Waste Dilution}

The addition of process water to a tank or to the tank waste by the PMP shall be minimized. 


\subsection{Maintenance}

\subsubsection{Service Interval}

The PMP shall be designed to operate for a minimum of 1000 hours over a two year span without scheduled or planned maintenance to the in-tank components being required. Exceptions may be made, subject to prior engineering approval.

\subsubsection{Maintainability}

The PMP shall be designed for manual replacement of the wearing parts while within the confinement and contamination control system confinement, using common glove-box techniques.

Human factors shall be taken into consideration and a modular design approach shall be implemented to ensure ease of equipment setup, operation, maintenance, and removal. All replacement parts and maintenance items shall be readily available within the United States.

\subsubsection{Decontamination}

Those portions of the PMP subject to being contaminated and requiring gross decontamination shall be designed to avoid cracks, crevices, or enclosed voids, which can entrap contamination and impair decontamination efforts.

The PMP is subject to gross decontamination operations and shall be designed to withstand high-pressure water spray of $3.4 \mathrm{MPa}$ (500-psig) maximum delivered through round jet nozzles at a rate of $6 \mathrm{l} / \mathrm{m} /$ nozzle $(1.5 \mathrm{gpm} /$ nozzle) from a distance not greater than $100 \mathrm{~mm}(4 \mathrm{in})$.

\subsection{Materials and Processes}

Materials and processes used in fabrication of the PMP system shall enable the equipment to comply with all design requirements specified in this document, including design life, operating and storage environments, and decontamination operations.

Material specification will be provided to ORNL prior to fabrication to allow comparison to US specifications. Materials selected shall meet or exceed US specifications for similar applications. All components designed and fabricated in the US (ex TRI,. Decontamination system) will be designed and fabricated to applicable standards (ASTM, ASME, etc). Proposed materials and standards for materials and fabrication (ex. ASTM, AISC) will be identified as part of the design submittal. 


\subsection{Interfaces}

The pulsating monitor system must interface with the GAAT facility.

\subsubsection{Diameter}

The maximum diameter for in-tank components is $57.1-\mathrm{cm}(22.5 \mathrm{in}){ }^{\mathrm{a})}$ This will enable the system to fit through the $59.7 \mathrm{~cm}$ (23.5-in.)-diameter risers with riser sleeve.

\subsubsection{Height}

The nominal height from the top of the platform to the bottom of the tank is $8.7 \pm 0.3 \mathrm{~m}$ ( 28.5 $\pm 1 \mathrm{ft})$ for tanks W-8 and W-9 or $5.6 \mathrm{~m}(18.5 \mathrm{ft})$ for tank TH-4. The PMP must be adjustable to accommodate insertion depths from the top of the service platform of 8.5 to $9.1 \mathrm{~m}$ (28 to $30 \mathrm{ft}$ ) or 5.5 to $6.1 \mathrm{~m}$ ( 18 to $20 \mathrm{ft}$ ). The system must be able to be inserted in up to $0.9 \mathrm{~m}(3 \mathrm{ft})$ of settled sludge.

\subsubsection{Load}

The PMP system will be mounted on the service platforms. The grating on these platforms is limited to live loads of $958 \mathrm{~N} / \mathrm{m}^{2}\left(20 \mathrm{lbf} / \mathrm{ft}^{2}\right)^{\mathrm{a}}$. The design must account for seismic and wind loading in addition to the weight of the PMP. The system may be designed to rest on existing platform structural steel. Any modifications or additional steel will be provided as part of the system and shall not impact installation of other equipment after the PMP is removed.

Loads applied directly on the tank riser should be minimized to the extent practical. If loads in excess of $8900 \mathrm{~N}$ (2000 lbs.) are to be applied to any riser, prior approval from the facility manager must be obtained.

The PMP shall be designed with adequate surface area at the bottom to prevent tank damage from anylive loads during operation. Static loads on the tank floor shall not exceed $5170 \mathrm{kPa}$ (750 psi) without prior approval from the facility manager.

\subsubsection{Utilities}

Connections must be made with site utilities. As a part of the design submittal, utility service information will be provided for the entire PMP system. This information will include compressed air pressure and flow rate, process water pressure and flow rate, and electrical voltage and amperage requirements.

a) Personal communication with Dirk Van Hoesen, July 1998.

a) Gunite and Associated Tanks, Platform Modifications Plan and Sections, A3E020539A001 Rev A. 
ORNL will provide a single connection point for compressed air at a maximum selected pressure and flow rate per the information in section 4 . Any additional piping, valving, pressure reduction or control, and flow control will be provided as part of the PMP system.

ORNL will provide a single connection point for process water at a selected pressure and flow rate per the information in section 4. Any additional piping, valving, pressure reduction or control, and flow control will be provided as part of the PMP system.

Fittings for all air and water piping that interfaces with ORNL connections must conform to US standards. Piping will conform to US standard sizes and be commonly used (nominal 1", 1.5 ", or 2" based on the required flow). Interfacing piping will be provided with US National Pipe Thread (NPT) fittings. Threads will comply with ANSI B1.20.1 (Inch) standards. ORNL will provide quick connect fittings as appropriate for the interfaces.

ORNL will provide a single electrical power feed at a selected voltage and maximum amperage per the information in Section 4. Any additional wiring, distribution, or voltage transformers will be provided as part of the PMP system. The only exception will be ORNL provided 120 volt, $60 \mathrm{~Hz}$ power at the control room and platform for operation of the control system computer.

The electrical interface will be a single, multi wire cable with wire size that meets minimum National Electrical Code requirements for the design voltage and amperage. ORNL will provide electrical connectors as appropriate for the interface.

\subsubsection{Hoisting and Rigging}

Provide lifting lugs and procedures that are in accordance with ORNL site requirements. Lifting equipment will be determined assuming the PMP vessel and piping is full of sludge and the system components will be lifted as a single unit.

ORNL will provide the applicable lifting and rigging specifications.

\subsection{Environmental Requirements}

The tank waste data was summarized in Section 5.0. Those portions of the equipment which are exposed to the interior of the waste tank must be designed to remain fully operational and achieve design life when subjected to the potential in-tank environment specified in Section 5.0.

No air emissions from in-tank equipment to the external environment are allowed.

No hazardous materials, such as oil, will be used without prior appropriate ORNL approvals. No lead-based paint/finishes, or exposed lead shielding or materials will be used. 


\subsection{Reviews}

As a minimum, the following reviews are required during system design and construction.

\subsubsection{Conceptual Design Review}

- Provide a list of equipment components.

- Provide a list of suggested materials of construction.

- describe interfaces between the PMP and the tank risers.

- IDENTIFY proposed over pressure protection devices.

\subsubsection{0\% Design Review}

- Provide revised piping and instrumentation drawings.

- Provide revised assembly drawings.

- Provide revised drawings detailing interfaces, supporting calculations where required, and load conditions.

- All drawings will be complete except for final signoffs.

- Calculations and supporting data, information, and references will be complete and include enough detail to permit a technically qualified reviewer to verify the design is consistent with applicable technical requirements from the codes and standards referenced in this document.

-

- Provide manufacturers data (i.e. cut sheets) on valves that identifies, as a minimum, materials of construction for body, seats, and internal components; pressure and temperature rating.

- Provide MSDS (material safety data sheets) for any chemicals used in operation.

\subsubsection{Procurement Certifications}

Provide material certifications or equivalent and the results of the acceptance tests for applicable components, such as the pressure vessel and piping, which are required to address plant safety and installation requirements and to verify construction in compliance with the design.

Counterfeit bolts: Bolts, nuts and washers for all structural connections shall conform to ASTM A307 or ASTM A325 requirements. Procurement from a pre-qualified vendor is recommended. For each shipment of bolts purchased for structural connections, obtain a Certificate of Conformance to ASTM A325. A receiving inspection is required for each shipment of ASTM A325 high-strength bolts for structural connections. 


\subsubsection{Acceptance Testing}

A specific test plan for the acceptance tests will be developed by the vendor and submitted for review and approval following the $90 \%$ design review. The test plan will identify specific tests to occur at the vendor facility prior to shipping and integrated tests that must occur at ORNL following receipt of all components. The vendor is responsible for administering all required tests, including those conducted by subcontractors. The acceptance test shall include as a minimum the following:

- Identify weld inspection/testing requirements and proposed information to be submitted to ORNL for review and approval prior to shipping.

- Ensure that acceptance tests conform to ORNL engineering specifications.

- Define test procedures and methods and demonstrate system integrity via system pressure tests that conform to applicable codes and standards.

- Demonstrate functionality of all controls and instrumentation.

- Demonstrate the riser interface.

- Demonstrate deployment, operation, and removal of the PMP.

- Describe cleaning, drying, and packaging requirements that will be completed following testing in preparation for shipment

- Identify test-reporting requirements, including documentation to be submitted.

Test reports and an acceptance report, including all required weld inspection information and weld inspection radiographic films, shall be prepared and submitted by the vendor prior to shipment.

A manufacturing and delivery plan will be prepared and submitted prior to testing that addresses, as a minimum: schedule for fabrication, testing, and delivery; packaging and shipping methods; and any special unloading and assembly instructions or requirements. The plan will identify maximum shipping weights and dimensions for each component, and ensure that packaging and bracing is adequate to prevent any damage during shipping or handling. Spare parts will also be addressed.

A draft operations and maintenance manual will be prepared and submitted along with a proposed list of spare parts following completion of the $90 \%$ design review.

Certified, as-built drawings and certified copies of test, examination, inspection, waivers, and deviations documents, along with certificates of compliance and materials certifications as required will be supplied prior to or at the time of shipment. Final certified drawings and documentation, including the operations and maintenance manual, will include enough detail of the control and mechanical systems to permit operation and maintenance by technically qualified personnel who are otherwise unfamiliar with the equipment or its operation. 


\subsection{Safety}

The GAAT Health and Safety officer or delegate will participate in the review of the pulsating mixer pump system during the system design, procurement, construction, installation, testing, operation, and removal phases at the GAAT south tank farm. The system design will be reviewed to assess both occupational and operational safety issues. The system must be designed to meet applicable OSHA standards.

Specific items that will be examined include:

- radiological issues such as: criticality safety, ALARA, double containment, remote handling, and system repair.

- installation issues such as: code compliance.

- operational issues such as: pressure vessel testing, hoisting and rigging.

- Occupational issues such as: human access, platforms, handrails, noise levels and need for hearing protection. 


\subsection{Quality Assurance}

Quality assurance requirements for the GAAT project, ORNL site, and DOE must be met during the design, construction, and deployment of the pulsating monitor system. All work must be conducted in accordance with these requirements.

\subsection{QA Requirements}

The GAAT project QA requirements are documented in the report: South Tank Farm Quality Assurance Project Plan, GAAT-RP/P-303 Rev 0.

\section{2}

Bechtel Jacobs Company LLC executes the Environmental Management and Integration contract of the U.S. Department of Energy Oak Ridge Operations Office and the GAAT project is managed bythis team. The Bechtel Jacobs Company QA program plan meets the requirements of the DOE.

\section{3}

The QA requirements for DOE sites such as ORNL are listed in the US Code of Federal Regulations: 10 CFR Part 830.120. Bechtel Jacobs Company and GAAT project Quality Assurance plans implement these requirements.

The vendor is responsible for preparing and submitting a QA plan that is adequate to ensure all work is accomplished in accordance with applicable codes, standards, and specifications and within approved specifications and fabrication drawings. The QA plan will address all aspects of the vendors work, including work performed by subcontractors. For components designed and/or manufactured outside the US, the QA plan will include a matrix that identifies, as a minimum, the following:

830.120 Requirement

List each requirement
ISO 9000

ID each that

corresponds to

830.120 reqmt.
Russian Standard

ID applicable code

or standard and section(s)

that implement

The vendor may be subject to QA surveillance's by Bechtel Jacobs Company and/or Lockheed Martin. These activities may include, but are not limited to, inspection and surveillance of 1) production activities; 2) production controls; 3) inspection of material 
certifications; 4) final inspections and tests; 5) shipping and handling activities; 6) document and drawing control; 7) purchasing controls; and 8) nonconformance control. Surveillance does not constitute acceptance nor relieve the vendor of the responsibility of furnishing an acceptable product.

\subsection{W elding}

All welding shall meet or exceed applicable US technical requirements and be performed in compliance with the appropriate national codes and standards for the work being performed. As a minimum, these standards shall address welder training and qualification, qualification and certification of welding inspectors, material specifications, nondestructive examination, welding procedure specifications, welding procedure qualification, and nondestructive examination procedures. The welding codes and standards will address both piping and structural welding as appropriate.

For components designed and fabricated in the US, structural welding will be per AWS D-1.1. Piping system welds will be per ASME B31.3. 


\subsection{References \& Bibliography}

Enderlin, CW, OD Mullen, and G Terrones. 1997. Performance Evaluation of the Quarter-Scale Russian Retrieval Equipment for the Removal of Hazardous Waste. PNNL-1:1740, Pacific Northwest National Laboratory, Richland, W ashington.

Martin Marietta Energy Systems, Inc. Results of Fall 1994 Sampling of Gunite and Associated Tanks at the Oak Ridge National Laboratory, Oak Ridge, Tennessee, ORNL/ER/Sub/87-99053/7.

Mullen, OD. 1998. Functions and Requirements for a Waste Conveyance Jet Pump for the Gunite and Associated Tanks at Oak Ridge National Laboratory. PNNL-11876, Pacific Northwest National Laboratory, Richland, W ashington.

Shekarriz, A, KJ Hammad, and MR Powell. 1997. Evaluation of Scaling Correlations for Mobilization. of Double-Shell Tank Waste. PNNL-11737, Pacific Northwest National Laboratory, Richland, Washington. 


\section{AGE \\ American Russian Environmental Servicos, Inc.}

January 12,1999

U.S. Department of Energy

Federal Energy Technology Center

P.O. Box 880, ATTN William Haslebacher, COR

3610 Collins Ferry Road

Morgantown, WV 26507-0880

Reference: Contract No. DE-AC26-98FT40500

Subject: Approved Functional Requirements

Dear Mr. Haslebacher:

I am enclosing the approved functional requirements for the Pulsating Mixing Pump System as required in the Statement of Work, Task 1.1 - Detailed Design.

Although the Functions and Requirements Document is not identified on the Reporting Requirements Checklist, I am forwarding a copy of the document in electronic form to the Contractor Reports Receipt Coordinator

Sincerely yours,

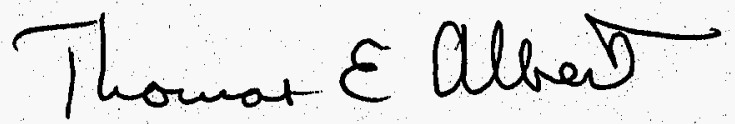

Thomas E. Albert

Cc: (Electronic Form Only)

U.S. Department of Energy

Federal Energy Technology Center

ATTN: Contractor Reports Receipt Coordinator

P.O. Box 10940, MS $921-143$

Pittsburgh, PA 15236-0940 